\title{
PENGARUH KEPEMIMPINAN, MOTIVASI DAN KEDISIPLINAN TERHADAP KINERJAPEGAWAI DAN DAMPAKNYA PADA KINERJA DINAS PERTANIAN KABUPATEN PIDIE
}

\author{
Boihaki \\ Program Studi Manajemen \\ Fakultas Ekonomi Universitas Jabal Ghafur
}

\begin{abstract}
The purpose of this study was to determine: (1) how leadership, motivation, discipline, employee performance and the performance of the Department of Agriculture Pidie District (2) the influence of leadership, motivation, self-discipline on the performance of employees, (3) the influence of leadership, motivation, self-discipline on the performance of the Office Agriculture Pidie district (4) the effect of an employee's performance against the performance of the Department of Agriculture Pidie and (5) the effect of leadership, motivation, discipline to employee performance through performance Pidie District Agricultural Office. This research was conducted at the Department of Agriculture Pidie district by the number of respondents as many as 125 people. As for the object of this study is to show that leadership, motivation, discipline, employee performance and the performance of the Department of Agriculture Pidie district already well underway, leadership, motivation and discipline either simultaneously or partially influence employee performance, leadership, motivation and discipline both simultaneously and partially also affect the performance of Pidie District Agricultural Office, employee performance directly affect the performance of the Department of Agriculture Pidie and leadership, motivation and discipline indirectly affect the performance of Pidie District Agricultural Office through the performance of employees.
\end{abstract}

Keywords : Leadership, Motivation, discipline, Employee Performance and Organizational Performance

\begin{abstract}
ABSTRAK
Tujuan penelitian ini adalah untuk mengetahui: (1) bagaimana kepemimpinan, motivasi, kedisiplinan, kinerja pegawai dan kinerja Dinas Pertanian Kabupaten Pidie (2) pengaruh kepemimpinan, motivasi, kedisiplinan terhadap kinerja pegawai, (3) pengaruh kepemimpinan, motivasi, kedisiplinan terhadap kinerja Dinas Pertanian Kabupaten Pidie (4) pengaruh kinerja pegawai terhadap kinerja Dinas Pertanian Kabupaten Pidie dan (5) pengaruh kepemimpinan, motivasi, kedisiplinan terhadap kinerja pegawai melalui kinerja Dinas Pertanian Kabupaten Pidie. Penelitian ini dilakukan di Dinas Pertanian Kabupaten Pidie dengan jumlah responden sebanyak 125 orang. Adapun yang menjadi objek penelitian ini adalah menunjukkan bahwa kepemimpinan, motivasi kerja, kedisiplinan, kinerja pegawai dan kinerja Dinas Pertanian Kabupaten Pidie sudah berjalan dengan baik, kepemimpinan, motivasi kerja dan kedisiplinan baik secara simultan maupun parsial berpengaruh terhadap kinerja pegawai, kepemimpinan, motivasi kerja dan kedisiplinan baik secara simultan maupun parsial juga berpengaruh terhadap kinerja Dinas Pertanian Kabupaten Pidie, kinerja pegawai memberikan pengaruh langsung terhadap kinerja Dinas Pertanian Kabupaten Pidie dan kepemimpinan, motivasi kerja dan kedisiplinan secara tidak langsung berpengaruh terhadap kinerja Dinas Pertanian Kabupaten Pidie melalui kinerja pegawainya.
\end{abstract}

Kata kunci : Kepemimpinan, Motivasi, Kedisiplinan, Kinerja Pegawai dan Kinerja Organisasi.

\section{PENDAHULUAN}

Dinas Pertanian Kabupaten Pidie adalah unsur pelaksana pemerintah daerah dibidang pembangunan pertanian. Pembangunan pertanian merupakan bagian integral dari pembangunan pertanian yang mempunyai peranan strategis dalam upaya pemantapan ketahanan pangan dan pemberdayaan ekonomi masyarakat diperdesaan. Pencapaian tujuan yang telah ditetapkan Ini tak lepas dari peran sumber daya manusia yang terdapat pada Dinas Pertanian Kabupaten Pidie. Berhasil atau tidaknya suatu organisasi dalam mencapai tujuannya tergantung oleh keberhasilannya dari para individu organisasi itu 
sendiri dalam menjalankan tugas mereka. Dalam setiap penggunaan sumber daya yang ada, sumber daya manusia merupakan salah satu unsur yang menentukan tercapainya tujuan organisasi secara efisien. pegawai akan mencurahkan segenap tenaga dan pikirannya untuk meningkatkan kinerja apabila mereka puas dalam bekerja, sehingga kepuasan kerja merupakan suatu hal yang sangat didambakan oleh setiap pegawai.

Suatu organisasi, baik itu pemerintah maupun swasta, selalu digerakan oleh sekelompok orang yang berperan aktif untuk mencapai tujuan yang ingin dicapai dari organisasi tersebut. Tujuan organisasi tentunya tidak akan tercapai jika kinerja anggota atau pegawainya tidak maksimal. Jadi dapat dikatakan bahwa dalam menjalankan roda organisasi, manusia merupakan unsur yang terpenting. Kinerja pegawai atau Prestasi kerja Dinas Pertanian Kabupaten Pidie dalam menjalankan tugas dan fungsinya banyak yang belum sesuai dengan tupoksi yang melekat dari masing-masing pegawai sesuai dengan fungsi dalam organisasi.

Dalam hal ini kemampuan pegawai dalam merealisasikan rencana yang telah dibuat juga masih relatif rendah hal ini dapat dilihat dari banyaknya pekerjaan yang tidak dapat diselasaikan dalam waktu yang telah ditentukan. Tanpa adanya dukungan oleh sumberdaya manusia yang handal, maka organisasi akan mengalami kesulitan untuk dapat bersaing dengan organisasi-organisasi lain.

Banyak faktor yang mempengaruhi kinerja organisasi, antara lain faktor kepemimpinan, faktor motivasi, faktor kedisiplinan, faktor kinerja pegawai. Sebagian pegawai menunjukkan disiplin kerja rendah dilihat dari absensi, pegawai yang tidak mengikuti apel di Dinas Pertanian Kabupaten Pidie, pegawai datang terlambat, masih adanya pegawai yang pulang lebih cepat, dari observasi dan informasi yang didapatkan dari Dinas Pertanian Kabupaten Pidie masih ditemukan adanya Karyawan yang suka duduk santai pada jam kerja, semangat untuk menjalankan aktivitas masih rendah.

Dalam hal ini peneliti ingin mengetengahkan tiga faktor, yaitu faktor kepemimpinan, faktor motivasi faktor kedisiplinan dan faktor kinerja pegawai. Pemilihan ini didasarkan pada kenyataan bahwa ketiga faktor tersebut paling sering muncul dalam teori yang membicarakan faktor-faktor yang berpengaruh terhadap kinerja pegawai.

Kedisiplinan kerja merupakan merupakan bentuk ketaatan dari perilaku seseorang dalam mematuhi ketentuan- ketentuan ataupun peraturan-peraturan tertentu yang berkaitan dengan pekerjaan, dan diberlakukan dalam suatu organisasi. Kedisiplinan kerja perlu dimiliki oleh setiap orang agar kehidupan organisasi bisa aman, tertib dan lancar. Hilangnya kedisiplinan kerja akan berpengaruh terhadap efisiensi kerja dan efektivitas tugas pekerjaan yang di bebankan padanya. Jika kedisiplinan tidak ditegakkan maka kemungkinan tujuan yang ditetapkan tidak akan dapat dicapai secara efektif dan efisien.

Dari uraian tersebut dapat dikatakan bahwa motivasi adalah sebagai salah satu faktor pendorong kinerja Pegawai, yang harus mendapat perhatian khusus dari pimpinan, jika menghendaki kinerja Pegawainya meningkat sehingga tujuan yang diharapkan bisa tercapai. Proses memotivasi sangat tergantung pada kemampuan pemimpin dalam mempengaruhi bawahannya dalam upaya untuk mewujudkan tujuan organisasi. Keberhasilan atau kegagalan yang dialami sebagian besar organisasi ditentukan oleh kualitas kepemimpinan, motivasi kerja dan kedisiplinan.

\section{KAJIAN KEPUSTAKAAN Kinerja Organisasi}

Kinerja organisasi merupakan capaian kerja yang dihasilkan secara bersama-sama oleh seluruh komponen sumber daya dalam suatu organisasi sesuai dengan target yang telah ditetapkan. Dalam penelitian ini kinerja organisasi yang dimaksudkan adalah hasil atau pencapaian dari hasil kerja seluruh sumber daya manusia pada Dinas Pertanian Kabupaten Pidie dalam memberikan pelayanan kepada masyarakat.

Bila dikaji dari tujuan dan misi utama kehadiran organisasi publik adalah untuk memenuhi kebutuhan dan melindungi kepentingan publik, kelihatannya sederhana sekali ukuran kinerja organisasi publik, namun tidaklah demikian kenyataannya, karena hingga kini belum ditemukan kesepakatan tentang ukuran kinerja organisasi publik.

Berkaitan dengan kesulitan yang terjadi dalam pengukuran kinerja organisasi publik ini dikemukakan oleh Dwiyanto (2007: 1), "kesulitan dalam pengukuran kinerja organisasi

Jurnal Sains Riset | Volume VIII Nomor I 
pelayanan publik sebagian muncul karena tujuan dan misi organisasi publik seringkali bukan hanya kabur akan tetapi juga bersifat multidimensional. Organisasi publik memiliki stakeholders yang jauh lebih banyak dan kompleks ketimbang organisasi swasta. Stakeholders dari organisasi publik seringkali memiliki kepentingan yang berbenturan satu dengan yang lainnya, akibatnya ukuran kinerja organisasi publik dimata para stakeholders juga menjadi berbeda-beda.

\section{Kinerja Pegawai}

Pengertian kinerja menurut Dale Timpe (2002:31), kinerja adalah tingkat prestasi seseorang atau karyawan dalam suatu organisasi atau perusahaan yang dapat meningkatkan produktifitas. Menurut Meiner (2005; 43) adalah sebagai kesuksesan yang dapat dicapai individu didalam melakukan pekerjaannya, dimana ukuran kesuksesan yang dicapai individu tidak dapat disamakan dengan individu yang lain. Kesuksesan yang dicapat individu adalah berdasarkan ukuran yang berlaku dan disesuaikan dengan jenis pekerjaannya. Dan Beyley (1982:56) dalam buku Subowo (2005:130), berpendapat bahwa kinerja berkaitan erat dengan tujuan atau sebagai suatu hasil dari perilaku kerja individu, hasil yang diharapkan dapat merupakan tuntutan dari individu itu sendiri.

Berdasarkan beberapa pendapat para ahli diatas dapat dijelaskan bahwa kinerja pegawai merupakan capaian prestasi seorang karyawan atau pegawai dalam suatu organisasi atau perusahaan yang dapat meningkatkan kualitas maupun kuantitas kerja sebagaimana yang diharapkan.

Kinerja karyawan mengacu pada prestasi seseorang yang diukur berdasarkan standar dan kriteria yang ditetapkan oleh perusahaan. Pengelolaan untuk mencapai kinerja sumber daya manusia tinggi dimaksudkan guna meningkatkan perusahaan secara keseluruhan (Fuad Mas'ud, 2004). Menurut Waldman (2004) kinerja merupakan gabungan perilaku dengan prestasi dari apa yang diharapkan dan pilihannya atau bagian syarat-syarat tugas yang ada pada masingmasing individu dalam organisasi. Sedangkan menurut Mangkunegara (2006) kinerja dapat didefinfisikan sebagai hasil kerja secara kualitas dan kuantitas yang dapat dicapai oleh seseorang karyawan dalam melaksanakan tugas sesuai dengan tanggung jawab yang diberikan kepadanya. Soeprihantono (2005) mengatakan bahwa kinerja merupakan hasil pekerjaan seorang karyawan selama periode tertentu dibandingkan dengan berbagai kemungkinan, misalnya standard, target/sasaran/kriteria yang telah ditentukan terlebih dahulu dan telah disepakati bersama.

\section{Kepemimpinan}

Menurut esensinya konsep kepemimpinan lebih luas dari konsep manajemen. Manajemen dipandang sebagai jenis khusus kepemimpinan dimana yang terpenting adalah pencapaian tujuan organisasi. Perbedaan pokok kedua konsep itu terletak pada istilah organisasi. Kepemimpinan terjadi pada setiap saat seseorang berusaha mempengaruhi perilaku seseorang atau kelompok orang apapun alasannya."

Kesimpulan yang dapat ditarik dari dua pendapat tersebut yaitu bahwa dalam lingkup yang lebih sempit atau organisasi kepemimpinan sebagai bagian dari proses manajemen dalam mencapai tujuan. Sedangkan dalam lingkup yang lebih luas manajemen merupakan bagian dari kepemimpinan. Artinya kepemimpinan tidak mutlak memerankan semua fungsi manajemen, tetapi sifat dan tujuan ataupun fokus dari kepemimpinan adlah bagaimana seseorang sebagai pemimpin dapat mempengaruhi seseorang atau sekelompok orang lainnya. Dalam kajiannya penulis memfokuskan pada fungsi pemimpin dalam proses memotivasi seperti telah dikemukakan sebelumnya mengenai peran kepemimpinan dalam motivasi. Bagian terpenting dalam hal ini terkait dengan bagaimana seorang pemimpin dapat dan mampu mengarahkan bawahannya dalam mencapai suatu tujuan atau goal yang ditargetkan untuk dicapai.

Gaya kepemimpinan adalah corak kepemimpinan yang dibawakan oleh seorang pemimpin dalam mempengaruhi para pengikutnya. Gaya seorang pemimpin dalam menjalankan kepemimpinannya dipengaruhi oleh berbagai patern, Wursanti, (2013:200), antara lain : patern pendidikan, patern pengalaman, patern usia dan patern karakter (tabiat atau sifat yang ada pada diri pemimpin tersebut.

\section{Motivasi}

Robbin (2002:55) dalam Brahmasari dan Suprayetno (2008:125) mengemukakan bahwa motivasi adalah keinginan untuk melakukan sebagai kesediaan untuk mengeluarkan tingkat upaya yang tinggi untuk tujuan organisasi, yang dikondisikan oleh kemampuan upaya itu untuk memenuhi suatu kebutuhan individual. Seorang 
individu melakukan sesuatu atas dasar keinginan serta adanya dorongan untuk memenuhi kebutuhan. Motivasi sebagai dorongan seorang individu menjadi sangat penting, tanpa adanya dorongan tersebut maka individu tersebut tidak termotivasi untuk melaksanakan tugas dan pekerjaan yang dibebankan.

Morrison (1993) dalam Hakim (2006:167) memberikan pengertian motivasi sebagai kecenderungan seseorang melibatkan diri dalam kegiatan yang mengarah ke sasaran. Jika perilaku tersebut mangarah pada suatu obyek atau sasarannya maka dengan motivasi tersebut akan diperoleh pencapaian target atau sasaran sebesarbesarnya sehingga pelaksanaan tugas dapat dikerjakan dengan sebaik-baiknya, sehingga efektifitas kerja dapat dicapai. Dengan adanya target atau sasaran itulah yang mengarahkan serta memotivasi karyawan untuk mengerjakan sesuatu.

Sarwoto berpendapat bahwa bahwa motivasi adalah proses pemberian motif (penggerak) bekerja kepada bawahan sedemikian rupa sehingga mau bekerja dengan ikhlas demi tercapainya tujuan organisasi secara efisien. Dengan adanya motivasi karyawan akan melaksanakan tugas yang dibebankan.

Pendapat Harold Koontz (1989) dalam Suharto dan Cahyono (2005:17) mengatakan bahwa motivasi sebagai suatu reaksi yang diawali dengan adanya kebutuhan yang menumbuhkan keinginan dan upaya mencapai tujuan yang selanjutnya menimbulkan tensi (ketegangan) yaitu keinginan yang belum terpenuhi, yang kemudian menyebabkan timbulnya tindakan yang mengarah pada tujuan dan akhirnya akan memuaskan keinginan. Sedangkan Robbins (2001) dalam Suharto dan Cahyono (2005:17) mendefenisikan motivasi sebagai kesediaan untuk mengeluarkan tingkat daya yang tinggi untuk tujaun organisasi, yang dikondisikan oleh kemampuan upaya itu dalam memenuhi beberapa kebutuhan individual.

Kedisiplinan.

Menurut Fathoni (2006) kedisiplinan adalah kesadaran dan kesediaan seseorang menaati semua peraturan perusahaan dan normanorma sosial yang berlaku. Kedisiplinan dapat diartikan bilamana karyawan selalu datang dan pulang tepat pada waktunya, mengerjakan semua pekerjaannya dengan baik, mematuhi semua peraturan perusahaan dan norma-norma sosial yang berlaku. Kedisiplinan harus ditegakkan dalam suatu organisasi perusahaan, karena tanpa dukungan kedisiplinan karyawan yang baik maka sulit perusahaan untuk mewujudkan tujuannya.

Berdasarkan pendapat-pendapat tersebut, dapat disimpulkan bahwa kedisiplinan kerja pegawai merupakan sikap atau tingkah laku yang menunjukkan kesetiaan dan ketaatan seseorang atau sekelompok orang terhadap peraturan yang telah ditetapkan oleh instansi atau organisasinya baik yang tertulis maupun tidak tertulis sehingga diharapkan pekerjaan yang dilakukan efektif dan efesien.

\section{METODE PENELITIAN \\ Lokasi dan Objek Penelitian}

Penelitian ini dilakukan pada Dinas Pertanian Kabupaten Pidie. Objek penelitian ini adalah seluruh pegawai Dinas Pertanian Kabupaten Pidie. Penelitian ini akan menyajikan tentang pengaruh kepemimpinan, motivasi kerja dan kedisiplinan terhadap kinerja pegawai serta dampaknya pada kinerja Dinas Pertanian Kabupaten Pidie

\section{Populasi dan Sampel}

Populasi dalam penelitian ini adalah seluruh Pegawai Dinas Pertanian Kabupaten Pidie berjumlah 125 orang. Sampel yang akan diambil dalam penelitian ini sesuai dengan metode yang berlaku yaitu metode sensus karena melibatkan seluruh anggota organisasi menjadi responden dalam penelitian ini, sehingga jumlah responden adalah 125 orang Pegawai Dinas Pertanian Kabupaten Pidie.

\section{Peralatan Analisis Data}

Suatu penelitian membutuhkan analisis data dan interpretasinya yang bertujuan menjawab pertanyaan-pertanyaan peneliti dalam rangka mengungakap fenomena sosial tertentu. Analisis data adalah proses penyederhanaan data ke dalam bentuk yang lebih mudah dibaca dan dinterpretasikan. Metode yang dipilih untuk analisis data harus sesuai dengan pola penelitian dan variabel yang akan diteliti, (Ferdinand, 2000).

Model yang digunakan dalam penelitian ini adalah model kausalitas (sebabakibat) yang digunakan hubungan dan pengaruh antara variabel bebas dengan variabel tergantungnya, serta faktor-faktor didalamnya. Untuk menganalisis data digunakan The Structural Equation Modelling (SEM) dengan menggunakan program AMOS. Permodelan 
dengan SEM memungkinkan dijawabnya pertanyaan penelitian secara dimensional, (Ferdinand, 2000).

Model persamaan struktural (SEM) adalah sekumpulan teknik-teknik statistikal yang memungkinkan pengujian sebuah rangkaian hubungan relatif murni "rumit" secara simultan (Ferdinand, 2000). Keunggulan aplikasi SEM dalam penelitian manajemen adalah karena kemampuannya untuk mengkonfirmasi dimensidimensi dari sebuah konsep atau faktor yang sangat lazim digunakan dalam manajemen serta kemampuannya untuk mengukur pengaruh hubungan-hubungan yang secara teoritis ada.

\section{HASIL PEMBAHASAN}

\section{Analisis Faktor}

\section{(ConfirmatoryFaktor Analysis)}

Konfirmatori

Analisis selanjutnya adalah analisis Structural Equation Model (SEM) secara full model, setelah dilakukan analisis terhadap tingkat uni dimensionalitas dari indikator-indikator pembentuk variabel laten yang diuji dengan confirmatory factor analysis. Analisis hasil pengolahan data pada tahap full model SEM dilakukan dengan melakukan uji kesesuaian dan uji statistik. Hasil pengolahan data untuk analisis full model SEM ditampilkan pada Gambar 1:

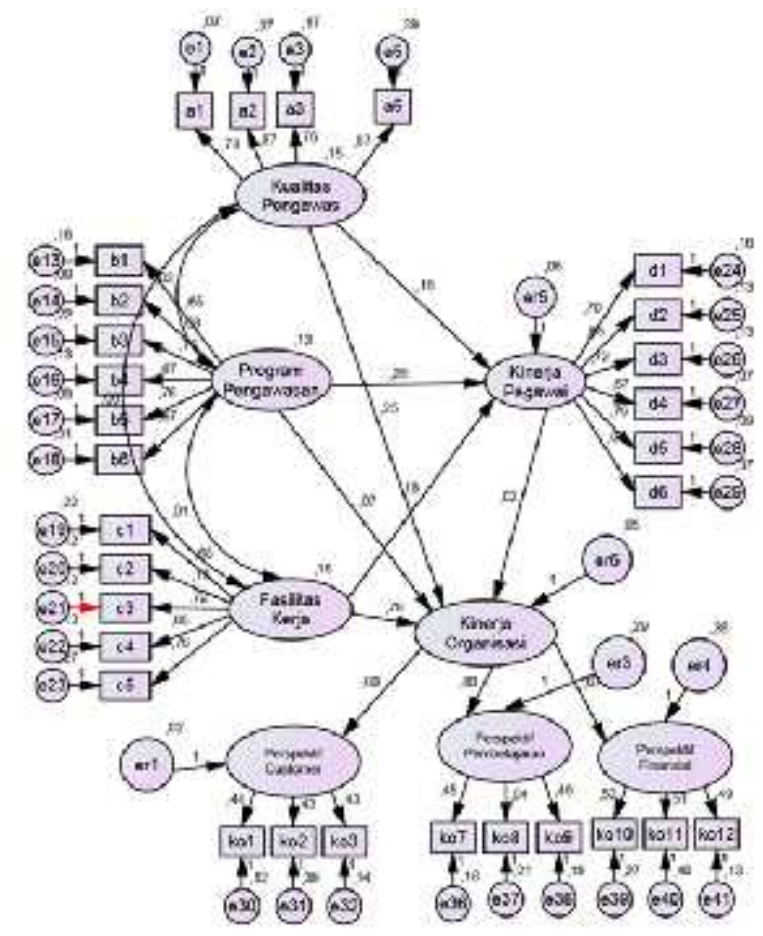

Gambar 1. Structural Equation Model

$$
\text { Pengaruh Kepemimpinan Terhadap }
$$

Parameter estimasi untuk pengujian pengaruh Kepemimpinan terhadap Kinerja pegawai Dinas Pertanian Kabupaten Pidie menunjukkan nilai CR sebesar 3,267 dan dengan probabilitas sebesar 0,000 . Kedua nilai yang diperoleh tersebut memenuhi syarat untuk penerimaan $\mathrm{H} 1$ yaitu nilai CR sebesar 3,267 yang lebih besar dari 1,97 dan probabilitas yang lebih kecil dari 0,05 .

\section{Pengaruh Motivasi Kerja Terhadap Kinerja Pegawai}

Parameter estimasi untuk pengujian pengaruh Motivasi kerja terhadap Kinerja pegawai Dinas Pertanian Kabupaten Pidie menunjukkan nilai CR sebesar 4,070 dan dengan probabilitas sebesar 0,000 . Kedua nilai tersebut diperoleh memenuhi syarat untuk penerimaan $\mathrm{H} 2$ yaitu nilai CR sebesar 4,070 yang lebih besar dari 1,97 dan probabilitas yang lebih kecil dari 0,05.

\section{Pengaruh Kedisiplinan Terhadap Kinerja Pegawai}

Parameter estimasi untuk pengujian pengaruh Kedisiplinan terhadap Kinerja pegawai Dinas Pertanian Kabupaten Pidie menunjukkan nilai CR sebesar 3,491 dan dengan probabilitas sebesar 0,000. Kedua nilai yang diperoleh tersebut memenuhi syarat untuk penerimaan $\mathrm{H} 3$ yaitu nilai CR sebesar 3,491 yang lebih besar dari 1,97 dan probabilitas yang lebih kecil dari 0,05.

\section{Pengaruh Kepemimpinan Terhadap Kinerja DinasPertanian Kabupaten Pidie}

Parameter estimasi untuk pengujian pengaruh Kepemimpinan terhadap kinerja organisasi Dinas Pertanian Kabupaten Pidie menunjukkan nilai CR sebesar 4,071 dan dengan probabilitas sebesar 0,000 . Kedua nilai tersebut diperoleh memenuhi syarat untuk penerimaan $\mathrm{H} 4$ yaitu nilai CR sebesar 4,071 yang lebih besar dari 1,97 dan probabilitas yang lebih kecil dari 0,05.

\section{Pengaruh Motivasi Kerja Terhadap Kinerja Dinas Pertanian Kabupaten Pidie}

Parameter estimasi untuk pengujian pengaruh Motivasi kerja terhadap kinerja organisasi menunjukkan nilai CR sebesar 4,388 dan dengan probabilitas sebesar 0,000. Kedua nilai tersebut diperoleh memenuhi syarat untuk penerimaan $\mathrm{H} 5$ yaitu nilai CR sebesar 4,388 yang lebih besar dari 1,97 dan probabilitas yang lebih kecil dari 0,05 . 


\section{Pengaruh Kedisiplinan Terhadap Kinerja Dinas Pertanian Kabupaten Pidie}

Parameter estimasi untuk pengujian

pengaruh Kedisiplinan terhadap kinerja organisasi Dinas Pertanian Kabupaten Pidie menunjukkan nilai CR sebesar 4,168 dan dengan probabilitas sebesar 0,000 . Kedua nilai tersebut diperoleh memenuhi syarat untuk penerimaan $\mathrm{H6}$ yaitu nilai CR sebesar 4,168 yang lebih besar dari 1,97 dan probabilitas yang lebih kecil dari 0,05.

\section{Pengaruh Kinerja Pegawai Terhadap Kinerja Dinas Pertanian Kabupaten Pidie}

Parameter estimasi untuk pengujian pengaruh Kinerja pegawai terhadap kinerja organisasi Dinas Pertanian Kabupaten Pidie menunjukkan nilai CR sebesar 4,125 dan dengan probabilitas sebesar 0,000. Kedua nilai tersebut diperoleh memenuhi syarat untuk penerimaan $\mathrm{H} 7$ yaitu nilai CR sebesar 4,125 yang lebih besar dari 1,97 dan probabilitas yang lebih kecil dari 0,05.

\section{KESIMPULAN DAN SARAN}

\section{Kesimpulan}

1. Hasil penelitian menunjukkan bahwa kepemimpinan, motivasi kerja, kedisiplinan, kinerja pegawai dan kinerja Dinas Pertanian Kabupaten Pidie sudah berjalan dengan baik.

2. Hasil penelitian juga membuktikan bahwa kepemimpinan, motivasi kerja dan kedisiplinan baik secara simultan maupun parsial berpengaruh terhadap kinerja pegawai Dinas Pertanian Kabupaten Pidie.

3. Hasil penelitian in juga membuktikan bahwa kepemimpinan, motivasi kerja dan kedisiplinan baik secara simultan maupun parsial juga berpengaruh terhadap kinerja Dinas Pertanian Kabupaten Pidie.

4. Kemudian hasil penelitian juga membuktikan bahwa kinerja pegawai memberikan pengaruh langsung terhadap kinerja Dinas Pertanian Kabupaten Pidie.

5. Sedangkan kepemimpinan, motivasi kerja dan kedisiplinan secara tidak langsung berpengaruh terhadap kinerja Dinas Pertanian Kabupaten Pidie melalui kinerja pegawainya.

\section{Saran}

1. Dalam rangka meningkatkan kinerja Dinas Pertanian Kabupaten Pidie berdasarkan perspektif kepemimpinan, maka yang harus dilakukan adalah pemimpinan harus mampu merangkul semua pegawai pada beberapa bagian dan bidang untuk saling bahu membahu memperbaiki kerja yang selama ini masih kurang baik, terutama kinerja yang berkaitan dengan pelayanan kepada masyarakat berkaitan dengan informasi penanaman padi, maupun informasi berkaitan

2. Motivasi kerja perlu lebih ditingkatkan lagi, terutama berkaitan dengan jaminan keamanan dan pemenuhan kebutuhan hidup pegawai, yaitu dengan cara menjamin keselamatan pegawai dalam menjalankan tugas seperti memberikan asuransi kesehatan dan kecelakaan kerja serta memberikan kompensasi sesuai dengan tugas dan tanggung jawab yang telah menjadi beban kerjanya.

3. Kemudian masalah kedisiplinan bagi setiap pegawai juga harus dapat ditingkatkan seperti pimpinan harus memberikan contoh dengan disiplin seperti masuk kerja tepat waktu dan pulang kantor juga sesuai dengan jam yang telah ditetapkan, serta memberikan sanksi tegas bagi pegawai yang melanggar disiplin kerja.

4. Dalam rangka meningkatkan kinerja pegawai dan Dinas Pertanian Kabupaten Pidie secara keseluruhan, maka yang harus ditingkatkan adalah pegawai harus mampu merealisasikan rencana kerja yang telah ditetapkan sebelumnya yaitu mencapai target kerja seperti realisasi dalam pemanfaatan anggaran untuk kepentingan masyarakat petani.

5. Dinas Pertanian Kabupaten Pidie sebagai suatu organisasi juga harus melakukan upaya-upaya guna meningkatkan pelayanannya terutama pelayanan informasi pertanian dan pelayanan dalam pemberantasan hama-hama tanaman seperti hama tikus yang hingg kini belum mampu diatasi oleh para petani, sehingga pihak Dinas Pertanian Kabupaten Pidie harus mampu mengatasi permasalahan tersebut, agar panen padi para petani dapat ditingkatkan.

\section{DAFTAR KEPUSTAKAAN}

Agrios, N. G. 2005. Plant Pathology- Fifth Edition. Departemen of Plant Pathology. University of Florida. United States of America. 
Ahmad Nur Rofi (2012) Pengaruh Disiplin dan Pengalaman Kerja Terhadap Prestasi Kerja Pada Departemen Produksi PT. Leo Agung Raya Semarang.

Amitai and Etzioni, Eva.(1964). Social Change, Sources, Patterns and onsequences. New York, London: Basic Books Inc Publishers.

Anogoro (2005), Pengaruh Perilaku Kepemimpinan Transformasional dan Transaksional Terhadap Kinerja Karyawan Lini Depan Perusahaan Jasa.

Anwar Prabu Mangkunegara, (2002), Manajemen Sumber Daya Manusia, PT. Remaja Rosda Karya, Bandung.

Danim (2007), Strategic Planning, Four Edition, Prentice Hall, USA

Dessler, G. (2006). Manajemen Sumber Daya Manusia. Jilid 1.Edisi 7. PT. Prenhallindo. Jakarta.

Dwiyanto (2007), Pengaruh Budaya terhadap Efektifitas Organisasi, Tarsito Bandung.

Fathoni, Abdurrahmat. 2006. Organisasi dan Manajemen Sumber Daya Manusia. Jakarta : Rineka Cipta.

Ferdinand Augusty, (2006), Structural Equation Modeling Dalam Penelitian Manjajemen, Aplikasi Model-Model Rumit Dalam Penelitian Untuk Tesis Magister \& Disertasi Doktor, Badan Penerbit Universitas Diponegoro

Gibson Ivannenich, dan Donnelly (2010), Organisasi, Edisi ke Lima Penerbit Erlangga, Jakarta.

Handoko. Hani T. (2011). Manajemen Personalia dan Sumber Daya Manusia. Edisi kedua. Yogyakarta. BPFE Universitas Gadjah Mada
Hasibuan, M. (2003). Organisasi dan motivasi , Jakarta : PT.Bumi Aksara.

Keputusan Menpan Nomor 63/KEP/M. PAN/7/2003, Tentang Standar Pelayanan.

Lembaga Administrasi Negara R.I (2000), Pengukuran Kinerja Pegawai, Jakarta.

Mahmudi, 2005, "Manajemen Kinerja Setor Publik", Akademi Manajemen Perusahaan YKPN.

Nitisemito (2005), Manajemen Sumber Daya Manusia, Jakarta, Penerbit Rineka Cipta.

Pasolong, Harbani.2007.Teori Administrasi Publik. Bandung : Alfabeta

Riduwan S. Sundjaja dan Inge Barlian, 2002, Manajemen Keuangan Satu, Edisi Keempat, Prenhallindo, Jakarta.

Rizky, Achmad S. 2001. Manajemen Pengganjian dan Pengupahan Karyawan Perusahaan, Cetakan pertama. Gramedia Utama. Jakarta.

Robbins, Stephans. (2006). Organization Theory, Structure, Design and Application, Alih Bahasa Yusuf Udara, Arean, Jakarta.

Robbins, Stephen P, 2002. Prinsip-prinsip perilaku Organisasi, Edisi Kelima, Alih Bahasa Halida,S.E. dan Dewi Sartika, S.S, Erlangga, Jakarta.

Saydam, (2007), Pengembangan Sumber Daya Manusia, Jakarta, Rineka Cipta.

Steers, M Richard. 2005. Efektivitas Organisasi. Jakarta: Erlangga.

Sugiyono. (2009). Metode Penelitian Bisnis (Pendekatan Kuantitatif, Kualitatif, dan R\&D). Bandung: Alfabeta.

Suma'mur, PK, 2008. Higene Perusahaan dan Kesehatan Kerja. Gunung Agung, Jakarta. 